Review Article

\title{
Review of the Geological Strength Index (GSI) as an Empirical Classification and Rock Mass Property Estimation Tool: Origination, Modifications, Applications, and Limitations
}

\author{
Sajjad Hussian $\left(D,{ }^{1}\right.$ Noor Mohammad, ${ }^{1}$ Zahid Ur Rehman, ${ }^{1}$ Naseer Muhammad Khan, \\ Khan Shahzada, ${ }^{4}$ Sarfraz Ali, ${ }^{5}$ Muhammad Tahir, ${ }^{1}$ Salim Raza, ${ }^{1}$ and Saira Sherin ${ }^{1}$ \\ ${ }^{1}$ Department of Mining Engineering, University of Engineering and Technology, Peshawar, Pakistan \\ ${ }^{2}$ Department of Mining Engineering, Balochistan University of Information Technology and Management Sciences (BUITMS), \\ Balochistan, Pakistan \\ ${ }^{3}$ School of Mines, China University of Mining and Technology, Xuzhou, China \\ ${ }^{4}$ Department of Civil Engineering, University of Engineering and Technology, Peshawar, Pakistan \\ ${ }^{5}$ Advanced School of Geo-Mechanical Engineering (SAGE), National University of Science and Technology, Islamabad, Pakistan \\ Correspondence should be addressed to Sajjad Hussian; engr.sajjad@uetpeshawar.edu.pk
}

Received 7 November 2019; Revised 19 July 2020; Accepted 30 July 2020; Published 24 August 2020

Academic Editor: Paolo Castaldo

Copyright (C) 2020 Sajjad Hussian et al. This is an open access article distributed under the Creative Commons Attribution License, which permits unrestricted use, distribution, and reproduction in any medium, provided the original work is properly cited.

\begin{abstract}
The geological strength index (GSI) is one of the most exceptional rock mass classification system which is used to evaluate very weak and highly jointed rock mass by different approaches and related to rock mass geomechanical properties including generalized Hoek \& Brown constants, deformation modulus, strength properties, and Poisson's ratio for an appropriate design of tunnels, caverns, and other engineering structures. The distinctiveness of this system over the rock mass rating (RMR), Q-system, and other empirical methods is as follows: it utilized field observations, blockiness of rock mass, and surface joint characteristics during the evaluation process of rock mass and efficiently espoused as an empirical tool for estimation of geomechanical properties of rock mass required for pre-post stability of engineering structures using numerical modeling. This study presents the review of the 19 years of research studies conducted by different researchers about the GSI in a systematic way, i.e., origination, modifications, applications, and limitations. Furthermore, this study will provide a better understanding to field professionals (geologists, mining and civil engineers) about the qualitative and quantitative estimation of the GSI and its application as an empirical estimating tool for an appropriate design of engineering structures in rock mass environments.
\end{abstract}

\section{Introduction}

The complex nature and uncertain behavior of rock mass due to anisotropic and presence of unconformities make the rock mass as difficult material for empirical and numerical modeling [1-5]. Modeling of such complex nature and uncertain behavior of rock mass in a precise way to decrease the uncertainty associated with the characterization process is quite complicated job [6]. Hudson and Feng [4] presented four primary modeling methods (A, B, C, and D) and eight submethods arranged in two levels for the solution/modeling of complex rock mass conditions using forward and back analysis-based design as shown in Figure 1.
The design process of engineering structure is started from site investigations and followed by the main four methods (A, B, C, and D) for completion of the project. At the preliminary stage of any rock engineering project, the detail data about geology and geotechnics of the area are not available for the proper design of engineering structures. Therefore, to deal with this situation, different rock mass classification systems called empirical methods of design have been developed for completion of the required design at the preliminary stage of the project [7-10]. The empirical methods of design are considered very helpful in rock mass characterization and classification into different classes having similar characteristics for quickly understanding and 


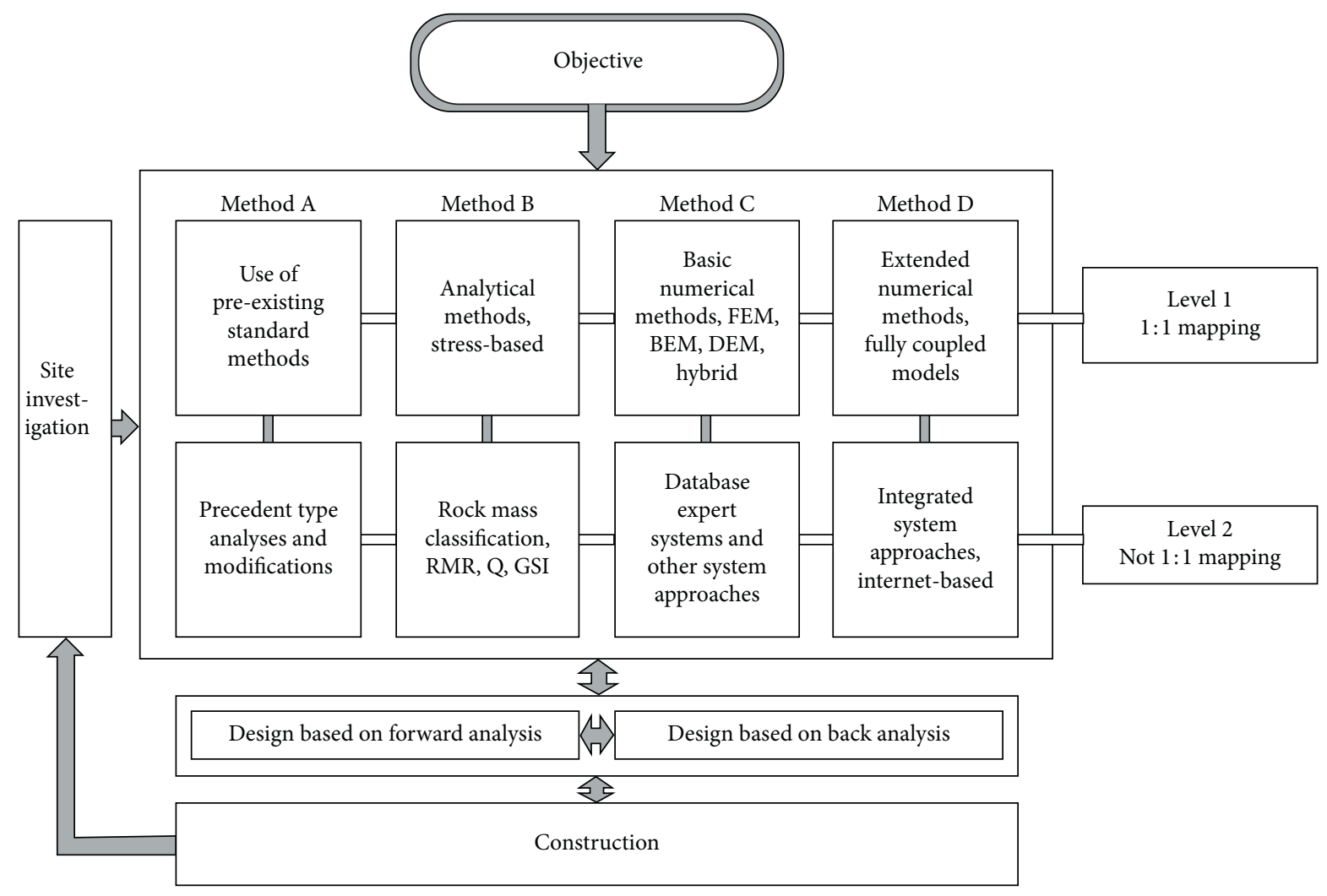

FIGURE 1: Summary of different methods for the solution of rock engineering problems [4].

the construction of underground engineering structures $[11,12]$ based on discontinuities and physiomechanical properties of rock mass for capturing the real image of the in situ conditions at the preliminary stage for effective design of engineering structures $[13,14]$. Numbers of empirical methods of design have been developed based on civil and mining engineering related case studies by various researchers in order to ensure the curative of the complex nature of rock mass for the design of tunnels, caverns, rock slopes, and general purposes as shown in Table 1.

These empirical methods have wide applications in the civil and mining fields. Each empirical approach used defined input parameters, including field observations and laboratory testing, for solving different aspects of rock engineering projects $[36,37]$. In the aforementioned empirical methods, RMR and Q-system are widely used classification systems for various purposes in rock engineering and considered as a base for the development of other classification systems $[28,33,38]$.

The rock mass rating (RMR) and tunneling quality index (Q-system) used rock quality designation (RQD) as an integral input parameter in the evaluation of rock mass quality for the design of a support system for underground structures [39]. The value of RQD is determined by core drilling, which is a very tedious procedure [17]. The procedure is cost-effective, and the value of RQD for a very weak rock is usually considered zero [17]. This condition leads to an estimation of the inappropriate value of RMR and Q-system for the classification of rock mass [40]. The RMR and
Q-system classification systems are mostly used for simple rock mass behavior, and these are less reliable to be used in squeezing, defined structural failures, rock bursting under very high-stress conditions, and estimation of rock mass properties for numerical modeling and less helpful in gaining information about the sequential installation of supports for controlling of progressive failure in weak rock mass conditions during tunneling construction [41]. Keeping in view of the above weaknesses of RMR and Q-system, the GSI rock mass classification system was developed. After development of the GSI system, different researchers, worldwide, have conducted research studies about the various aspects of the GSI system to accommodate and evaluate weakest, jointed, and heterogeneous rock mass environment for design of engineering structures and numerical modeling $[11,13,41-57]$. The research conducted so far on GSI is not comprehensive reviewed in a systematic way, therefore, it is very important, to carry out a systematic and comprehensive review of the research conducted about the various aspects of GSI system in order to provide a better understanding to field professionals (geologists, mining and civil engineers) about the GSI system and its application as an empirical classification and rock mass property estimation tool for an appropriate design of engineering structures and numerical modeling.

In this study, a review of 19 years of research conducted by different researchers about the various aspects of the GSI is presented in a systematic way. The review about the GSI is divided into four categories, i.e., origination, modifications, 
TABLE 1: Empirical methods for rock mass classification and design of engineering structures in rock mass.

\begin{tabular}{|c|c|c|c|c|c|}
\hline S. no & Empirical method & Year & Applications & Authors & Reference \\
\hline 1 & Rock load & 1946 & Tunnels with steel support & Terzaghi & [15] \\
\hline 2 & Stand-up time & 1958 & Tunneling & Lauffer & {$[16]$} \\
\hline 3 & Rock quality designation (RQD) & 1963,1966 & Tunneling & Deere and Miller & {$[17,18]$} \\
\hline 4 & Rock structure rating (RSR) & 1972 & Tunneling & Wickham et al. & {$[19]$} \\
\hline 5 & Rock mass rating (RMR) & $\begin{array}{l}1973 \text { (modifications } \\
\text { 1989) }\end{array}$ & Tunnels, mines, slopes & Bieniawski & {$[20,21]$} \\
\hline 6 & Tunneling quality index (Q) & $\begin{array}{c}1974 \text { (last } \\
\text { modification 2002) }\end{array}$ & $\begin{array}{l}\text { Tunnels, mines, } \\
\text { foundations }\end{array}$ & Barton et al. & {$[22]$} \\
\hline 7 & New Austrian tunneling method (NATM) & 1974 & Tunneling & $\begin{array}{l}\text { Pacher and } \\
\text { Rabcewicz }\end{array}$ & {$[23]$} \\
\hline 8 & Size strength classification & 1975 & Tunneling & Franklin & {$[24]$} \\
\hline 9 & Basic geotechnical classification (BGC) & 1981 & General & ISRM & {$[25]$} \\
\hline 10 & Rock mass strength (RMS) & 1982 & Metal mining & Stille and Groth & {$[26]$} \\
\hline 11 & $\begin{array}{c}\text { Unified rock mass classification system } \\
\text { (URCS) }\end{array}$ & 1984 & General & $\begin{array}{l}\text { Williamson and } \\
\text { Kuhn }\end{array}$ & {$[27]$} \\
\hline 12 & Rock mass index (RMi) & 1996 & Tunneling & Palmström & {$[28]$} \\
\hline 13 & Geological strength index (GSI) & 1997 & $\begin{array}{l}\text { All underground } \\
\text { excavations }\end{array}$ & Hoek and Kaiser & {$[29]$} \\
\hline 14 & $\begin{array}{c}\text { Rock tunneling quality index by TBM } \\
\text { excavation }\left(\mathrm{Q}_{\mathrm{TBM}}\right)\end{array}$ & 1999 & TBM tunnels & Barton & {$[30]$} \\
\hline 15 & Continuous rock mass rating (CRMR) & 2003 & General & Sen and Bahaaeldin & {$[31]$} \\
\hline 16 & Rock mass excitability (RME) & 2006 & TBM tunnels & $\begin{array}{l}\text { Bieniawski von } \\
\text { Prein et al. }\end{array}$ & {$[32]$} \\
\hline 17 & Rock mass quality rating (RMQR) & 2015 & General & Aydan et al. & {$[33]$} \\
\hline 18 & $\begin{array}{l}\text { Modification of the rock mass rating system } \\
\text { (rock Bolt Supporting factor (RSF)) }\end{array}$ & 2017 & $\begin{array}{l}\text { Tunneling and } \\
\text { underground excavations }\end{array}$ & $\begin{array}{l}\text { Mohammadi and } \\
\text { Hossaini }\end{array}$ & {$[34]$} \\
\hline 19 & Anisotropic rock mass rating (ARMR) & 2018 & Tunneling and general & Saroglou et al. & {$[35]$} \\
\hline
\end{tabular}

applications, and limitations, in order to provide a better understanding to field professionals (geologists, mining and civil engineers) about the qualitative and quantitative estimation of the GSI for assessment of rock mass and use the GSI as an empirical estimating tool for an appropriate design of engineering structures in rock mass environments.

\section{Origination of the Geological Strength Index (GSI)}

After reviewing the empirical methods of design as presented in Table 1, the following grounds are identified for the development of the GSI:

(a) RQD is an integral part of RMR and Q-system. In weak rock mass conditions, RQD value is taken as zero using Deree et al. procedure and equation (1) [58]. This condition leads to an estimation of the inappropriate value of RMR and Q-system for rock mass classification [40].

(b) RMR, Q-system, and other rock mass classification systems are inconvenient to provide information about the requirement of the support system in complex tunneling conditions for controlling progressive failure and design of proper sequentially installed temporary supports, and on the contrary, the numerical methods are considered very effective to give detail information about this situation. The numerical methods used the physiomechanical and deformation properties of rock mass surrounding the tunnel as input parameters.
These properties of the rock mass are difficult to measure in the field due to uncertain rock mass conditions and challenging procedure $[7,40,58-60]$. Researchers are now focused on estimating the rock mass properties rather than finding in the field [61]. In this regard, the first attempt was made to estimate the rock mass properties by Hoek and Brown in 1980 [61]. Hoek and Brown developed failure criteria to estimate the rock mass properties. It was realized after the development of Hoek and Brown's failure criteria that this failure criterion should be linked with actual geological observations of the field to gain its practical value [41]. Thus, in this context, the development of the geological strength index (GSI) was started in Toronto with taking engineering geology as input from David Wood in 1992 by Hoek et al. to classify weak and jointed rock mass environments.

$$
\begin{aligned}
\mathrm{RQD}= & \left.\sum \text { (length of core pieces }>10 \mathrm{~cm} \text { length }\right) \\
& \times \frac{100}{\text { total length of core run }} .
\end{aligned}
$$

\section{Geological Strength Index (GSI)}

The geological strength index (GSI) is a rock mass characterization tool developed for the design of tunnels, caverns, and other underground structures based on field observations including geological data about rock mass, inputs from qualified and expertise field geologists/ 
engineers about the visual impression of the rock structure including block and surface condition of the discontinuities represented by joint characteristics (roughness and alteration) and providing reliable data in the form of rock mass strength properties which are used as input parameters for numerical analysis or closed-form solutions $[41,46,50,55,62]$. The GSI classification system has gained wide acceptance as an empirical tool for estimating the strength and deformation characteristics of heavily jointed rock masses [11]. The development process of the GSI was started in Toronto, Canada, taking input about engineering geology from David Wood by Hoek et al. [41, 44]. The GSI was further linked with Hoek and Brown failure criterion to estimate rock mass properties in true spirit in 1994 as presented by Hoek and Kaiser in 1995 [29] and Hoek and Brown in 1997. The GSI system classifies the rock mass environment into five categories ranging from very good to very poor based on the field observations about the rock mass structure ranging from blocky to disintegrated (poorly interlocked and heavily broken rock mass) $[43,61,63]$. The numeric value of the GSI is estimated from the quantified diagonal lines ranging from 10 to 80 and having an interval of 5 . The quality of rock mass is divided into five categories and four rock mass structure domains. The basic GSI chart is presented in Figure 2.

\section{Modifications in the GSI}

The GSI rock mass classification system was updated and modified from time to time, keeping in view its applicability and the mode of assessment of rock mass and estimation of rock mass strength properties. The details of the review of the improvements and modification in the GSI system made by different researchers are described in the following paragraphs.

Hoek, in 1994 [63], linked the Hoek and Brown failure criterion, and its constants with each surface quality of rock mass of the basic GSI chart in order to achieve the primary estimating objective of the GSI system for each rock mass structure domain as presented in Figure 3 without changing the rock mass structure domain and quality in the basic GSI chart. The estimating parameters for each rock mass quality and structure domain includes Hoek and Brown constants $(s, a)$, rock mass deformation modulus $\left(E_{m}\right)$, and Poisson's ratio $(v)$.

Hoek et al., in 1998 [43], made an extension in the GSI classification system to accommodate the weakest Athens Schist rock masses. The foliated/laminated/sheared rock mass category of the said area has been added to the basic GSI chart to represent thinly laminated, foliated, and structurally sheared weak rocks. The rock mass included in this category is not associated with good to very good surface quality, while it is associated with poor to very poor surface quality; due to its poor rock mass quality and shear behavior, the rock mass falls into disintegrated and foliated/laminated categories having the GSI value ranging from 5 to 30 [43]. The extension in the GSI is shown in Figure 4.

From 1974 to 1998 , the GSI value is estimated qualitatively based on thorough geological visual observations of field and expertise of professionals about collecting data. The degree of correctness of the GSI value mainly depends on the expertise of the data collector and vice versa. It means that the GSI value may be estimated differently by different people based on the degree of expertise [47]. Therefore, it was essential to overcome these difficulties in the estimation of the GSI value. The era of switching from qualitative to quantitative estimation of the GSI value started in early 1999 in order to estimate the GSI value appropriately as possible. In this regard, the first attempt was made by Sonmez and Ulusay in 1999 to develop a refined quantitative numerical basis for estimating the GSI value, to suggest quantities for estimation of rock mass strength as an additional tool, and to apply the GSI in the stability analysis of slopes [52]. During the development of the quantification of the GSI chart, Sonmez and Ulusay did not consider the extension made in the basic GSI chart by Hoek et al. [43]. For GSI quantification, Sonmez and Ulusay suggested structure rating (SR) based on $J_{v}$ (volumetric joint count), which describes the rock mass structure and surface condition rating (SCR) based on roughness, weathering, and infilling nature of joints. SCR was calculated using a rating of $R_{r}, R_{w}$, and $R_{f}[21,64]$. The total rating of SCR is obtained using the following equation [52]:

$$
\mathrm{SCR}=R_{r}+R_{w}+R_{f}
$$

where $R_{r}, R_{w}$, and $R_{f}$ represent roughness, weathering, and infilling, respectively.

The SCR maximum range of the rating is 18 , and the SCR axis is divided into 18 equal parts as shown in Figure 5.

$J_{v}$ is estimated from a joint survey about block size using equations (3) and (4) [52]:

$$
\begin{aligned}
& J_{v}=\frac{N_{1}}{L_{1}}+\frac{N_{2}}{L_{2}}+\frac{N_{3}}{L_{3}}+\cdots+\frac{N_{n}}{L_{n}}, \\
& J_{v}=\frac{1}{S_{1}}+\frac{1}{S_{2}}+\frac{1}{S_{3}}+\cdots+\frac{1}{S_{n}},
\end{aligned}
$$

where $S$ is joint spacing, $N$ is the number of joints along scanline, $L$ is the scanline length, and $n$ is the joint set number. Equations (3) and (4) are used when there are limited joints available, and the rock may deal as isotropic and homogenous. For highly joint conditions, Sonmez and Ulusay suggested the following equation to be used [52]:

$$
J_{v}=\frac{N_{x}}{L_{x}} \times \frac{N_{y}}{L_{y}} \times \frac{N_{z}}{L_{z}} \cdots .
$$

It is complicated to assess joints in all directions during a scanline joint survey; therefore, for easiness, the rock mass is assumed as a homogenous material. For this condition, equation (5) is simplified as

$$
\mathbf{J}_{\mathbf{v}}=\left(\frac{\mathbf{N}}{\mathbf{L}}\right)^{3}
$$

Marinos and Hoek, in 2000 and 2001, thoroughly worked on incredible jointed rock masses surrounding the tunnels in Greece and included the intact/massive category in the structure domain and joint characteristics in the GSI 


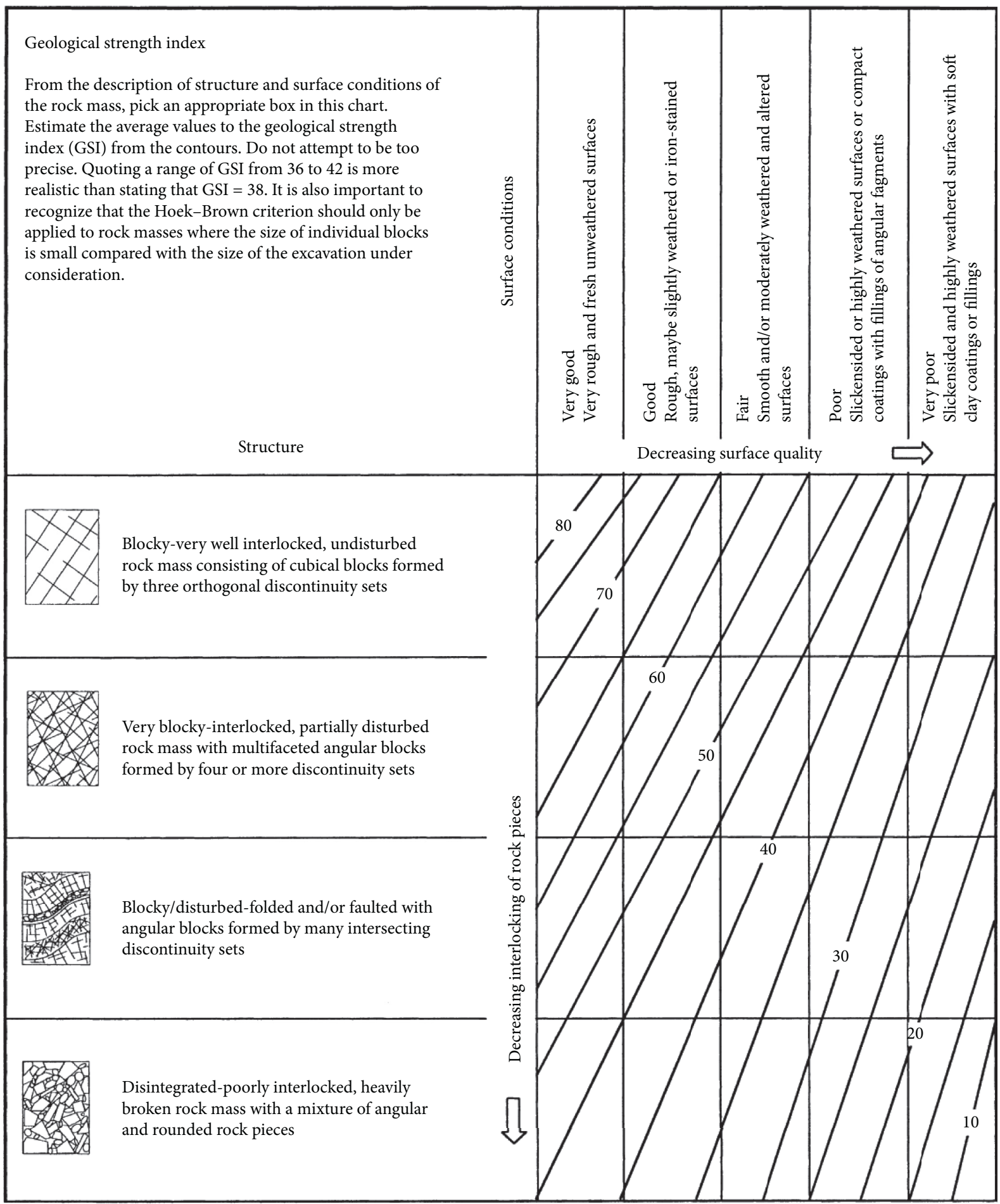

Figure 2: GSI basic chart $[43,61,63]$.

chart from lithology, structure, and surface conditions of rock mass discontinuities $[42,45,48]$ as shown in Figure 6.

Cai et al., in 2004 [50] introduced block volume (Vb), joint condition $\left(J_{c}\right)$ factor for quantifying GSI value and insert massive block segment in structure domain of GSI as shown in Figure 7. Inserting these parameters not only decreased the dependency on field experience required for estimation of GSI value but also maintained the simplicity of GSI chart developed by Marinos and Hoek in 2000 and 2001. The influence of these two parameters, i.e., $V_{b}$ and $J_{c}$, were calibrated using published data and further verified on two caverns as case studies based on the back analysis technique. The block volume is determined by the following equation: 


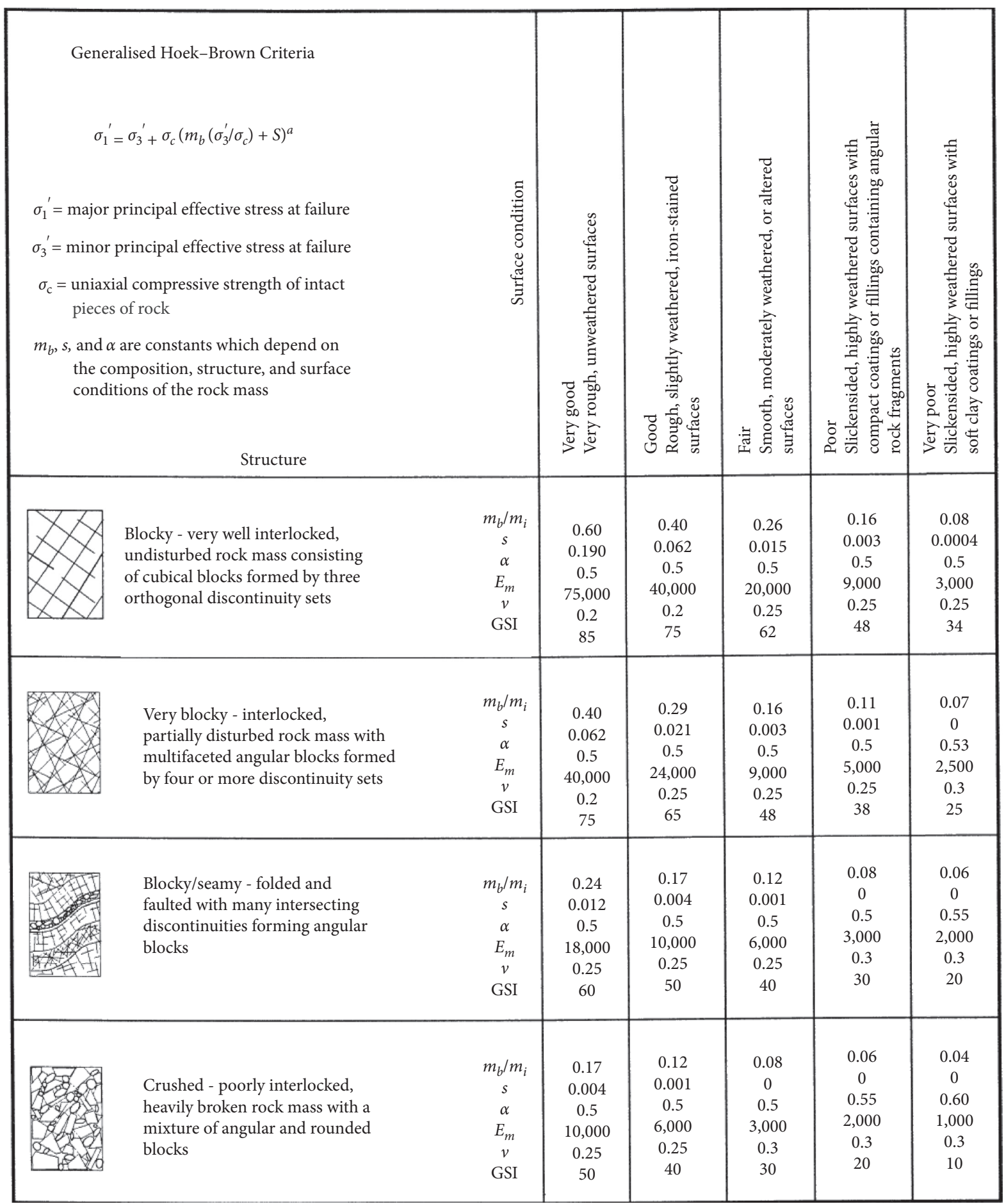

FIgURE 3: Hoek and Brown failure criterion linkage with the GSI [63].

$$
V_{b}=\frac{s_{1} \times s_{2} \times s_{3}}{\sin \gamma_{1} \times \sin \gamma_{2} \times \sin \gamma_{3}}
$$

where $s$ is joint spacing and $\gamma$ is the angle between joint sets, as shown in Figure 8.

Due to variations in joint spacing, the effect of $\gamma$ between joint sets is relatively small. Therefore, the block volume can be estimated for practical purpose as

$$
V_{b}=s_{1} \times s_{2} \times s_{3} .
$$

Since joints are discontinued, it is essential to determine equivalent block volume using the following equation:

$$
V_{b}=\frac{s_{1} \times s_{2} \times s_{3}}{\sqrt[3]{P_{1} \times P_{2} \times P_{3}}} \times \frac{1}{\sin \gamma_{1} \times \sin \gamma_{2} \times \sin \gamma_{3}},
$$




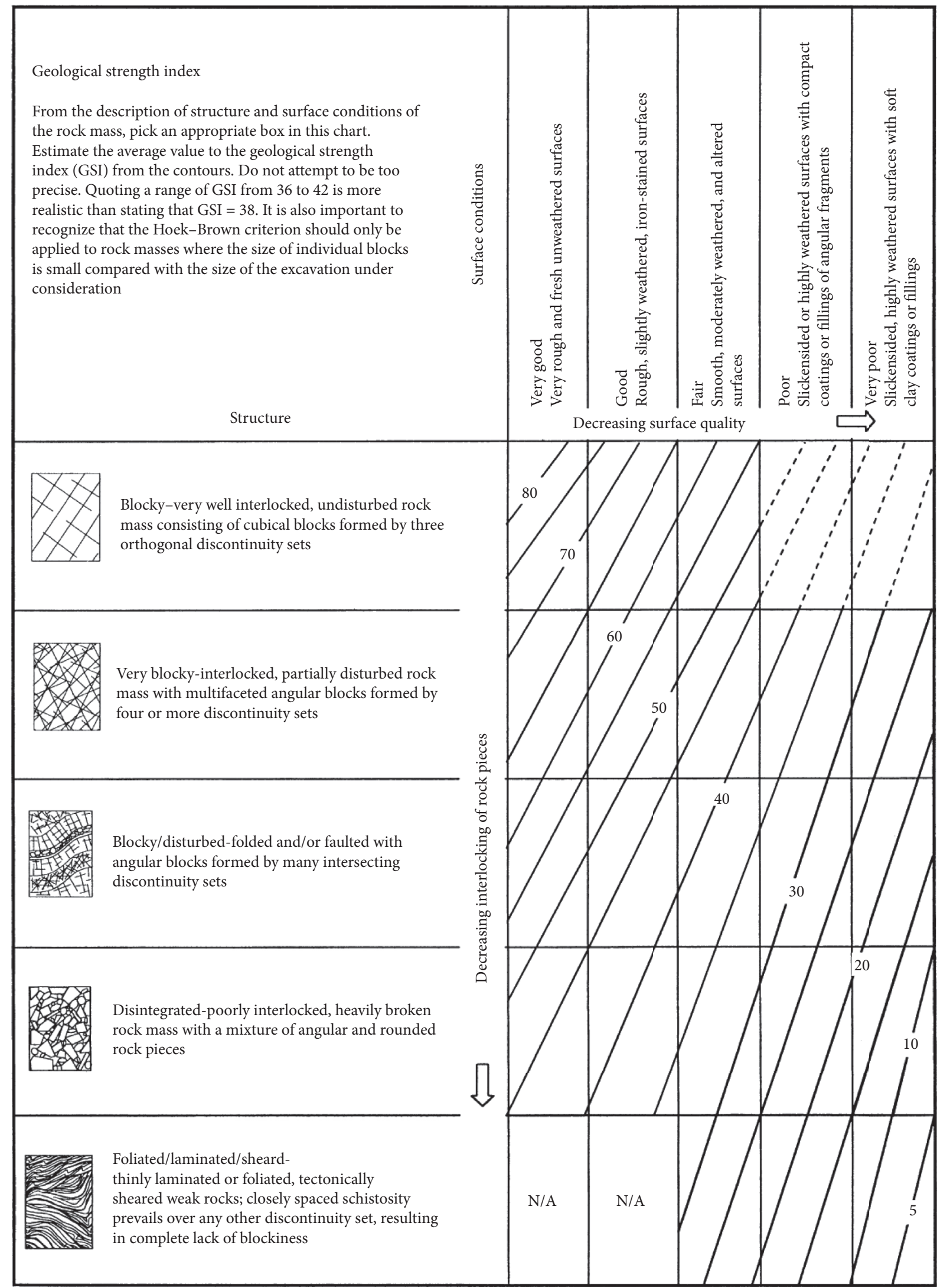

FIgURE 4: Extension in the basic GSI chart [43]. 


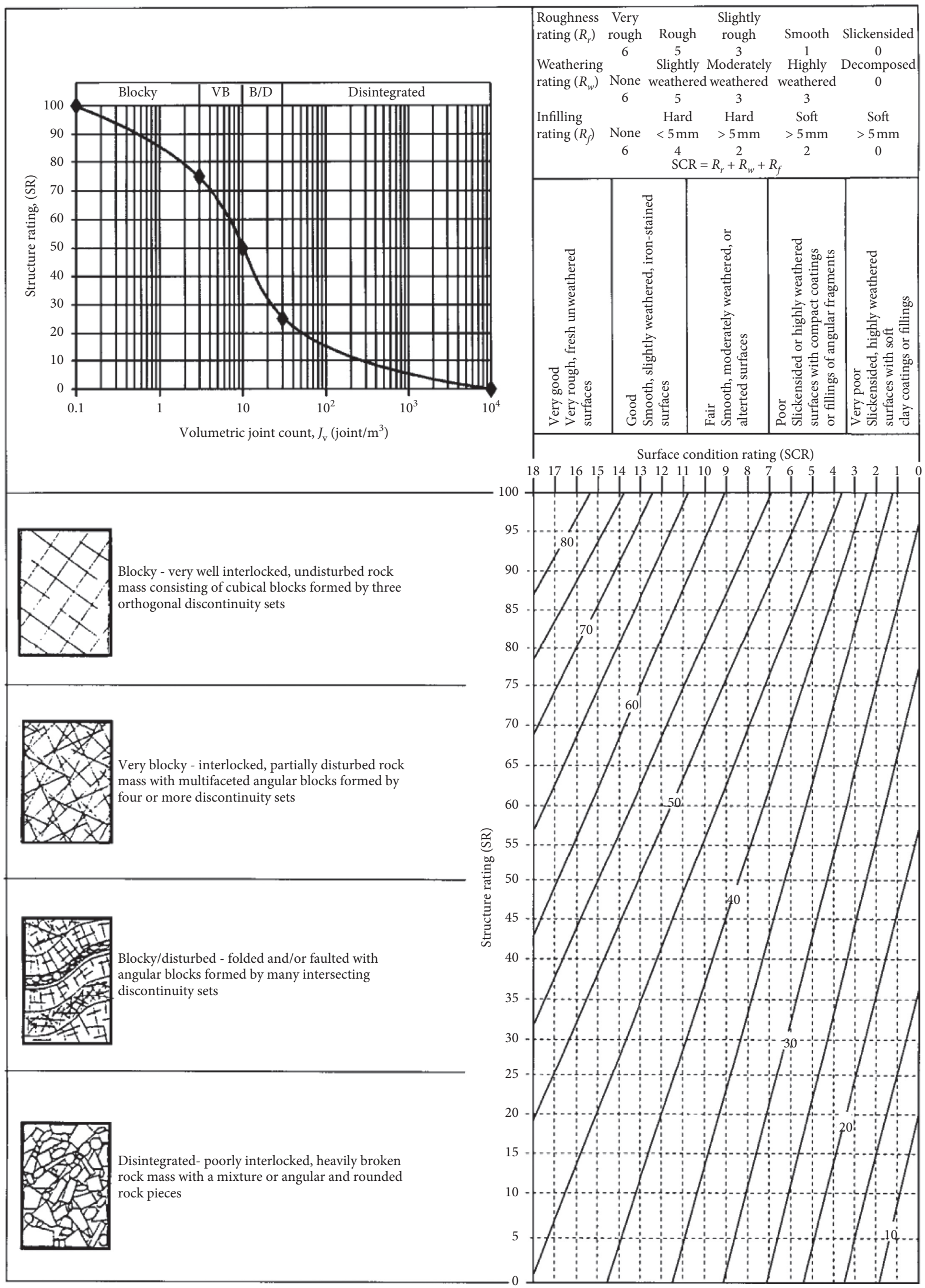

FIgURE 5: Quantification of the GSI chart [52]. 


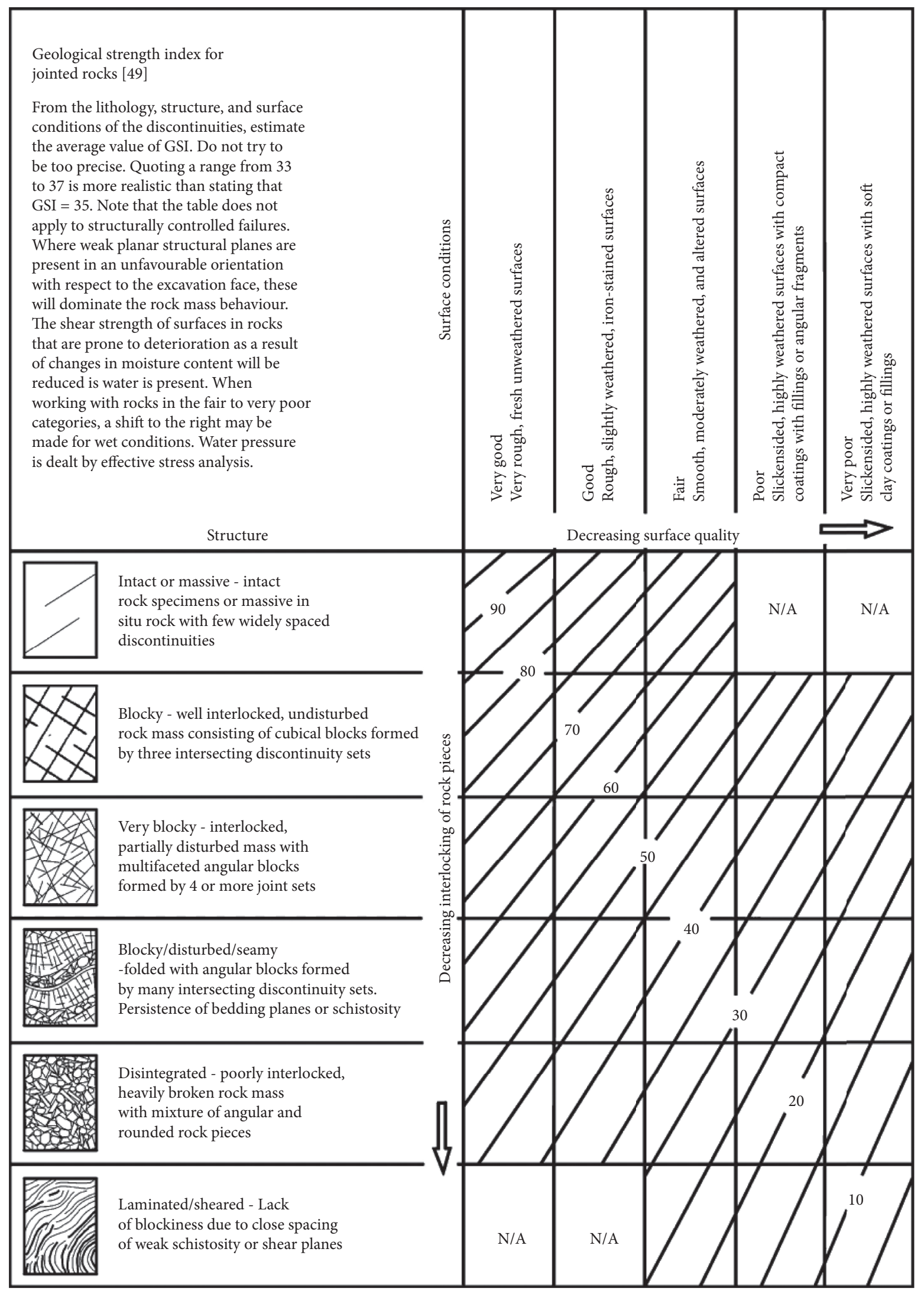

FIGURE 6: GSI chart for jointed rock mass [42, 45, 48]. 


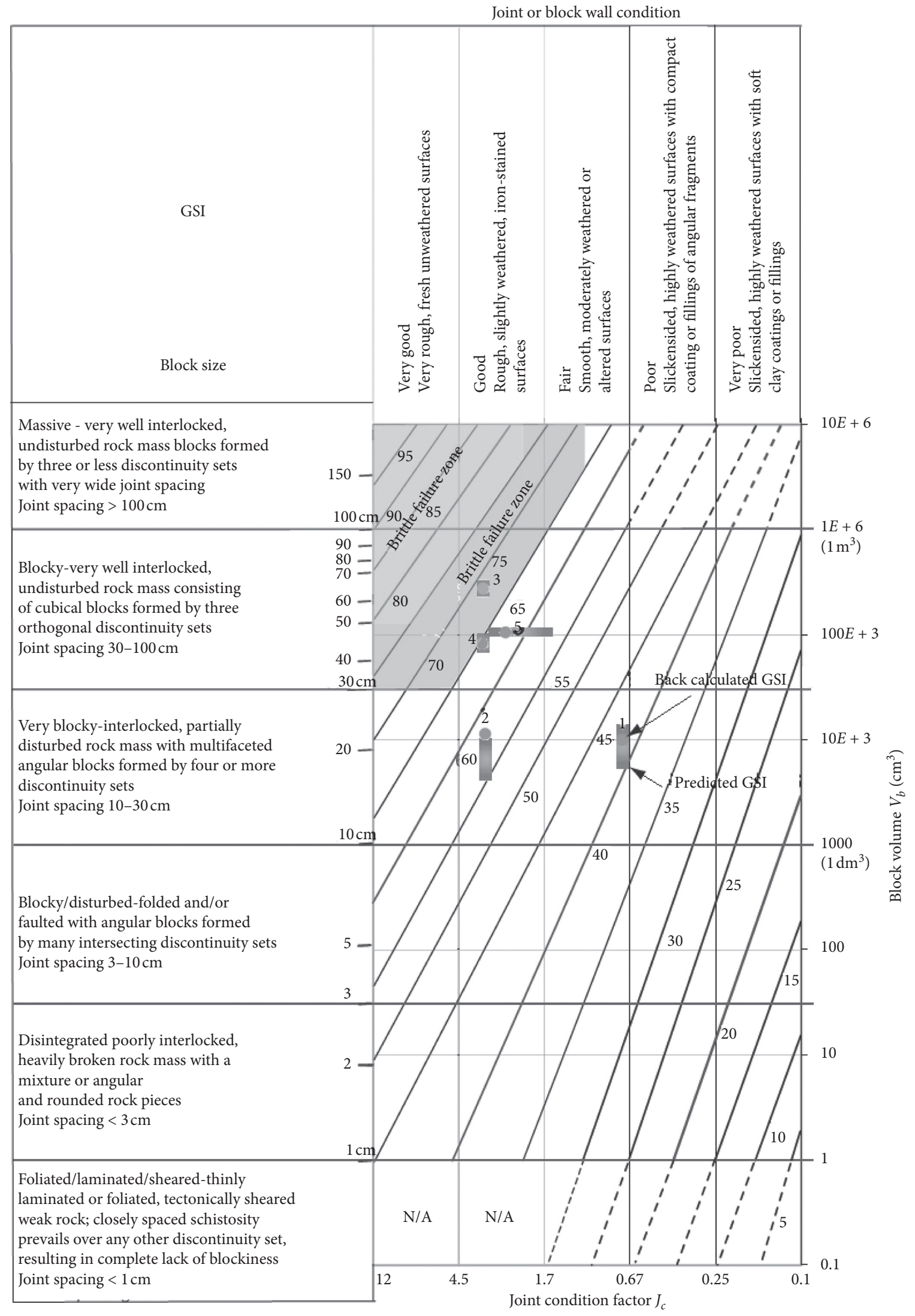

FIgURE 7: GSI quantification chart [49]. 


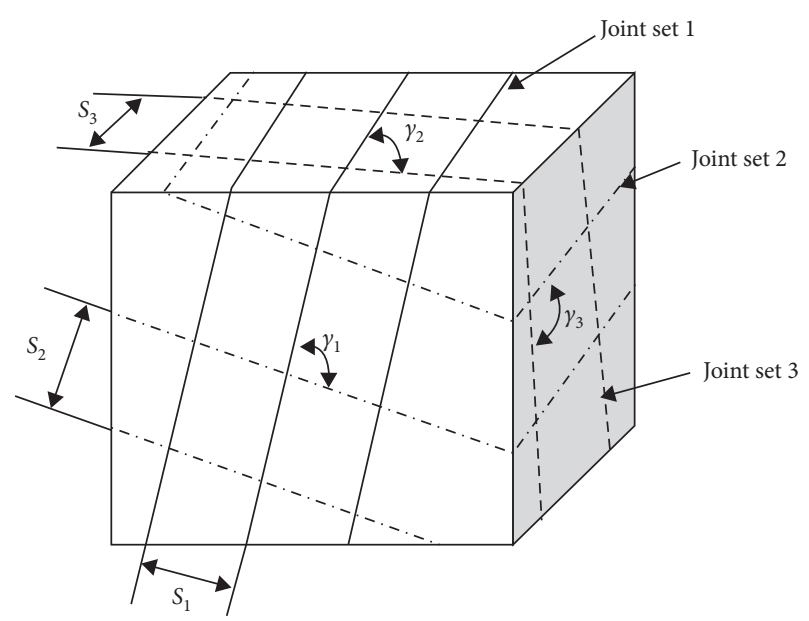

Figure 8: Joint sets and angle between joint sets [49].

where $P$ is the joint persistent factor.

The joint condition factor, similar to the factor used by Palmstrom [28], is determined by the following equation:

$$
J_{c}=\frac{J_{s} \times J_{w}}{J_{a}}
$$

where $J_{s}, J_{w}$, and $J_{a}$ are joint spacing, roughness, and alteration ratings.

Hoek et al., in 2005 [64], incorporated weak, heterogeneous rock masses, and lithological variability of a rock mass. Hoek et al. developed two charts for confined and fissile molaissic rock masses for tunnels and surface excavations.

Hoek et al., in 2013, inserted scales at the $x$-axis and $y$ axis represented by $\mathrm{A}$ and $\mathrm{B}$, respectively, in the GSI chart developed by Hoek and Marinos 2000. Scale A is representing the surface quality of rock mass, having a range from 0 to 45 divided into 5 divisions at an interval of 9 . Scale B is representing block interlocking and structure domains of the rock mass, having a range from 0 to 50 divided into 5 divisions at an interval of 10 [13].

Furthermore, Marinos and Hoek defined scale A by 1.5 JCond $_{89}$, and scale B is defined as RQD/2 in the basic GSI chart, as shown in Figure 9.

\section{Applications of the GSI as an Empirical Estimation Tool for Geomechanical Properties of Rock Mass}

The GSI system is explicitly used in estimations of rock mass strength and deformation properties based on Hoek and Brown failure criterion for numerical modeling and analysis of projects in rock engineering $[8,9,11,22,39-41,43,47$, $49-51,53,54,61,64-73]$. The exceptionality of the GSI over other empirical methods (RMR, Q-system, etc.) is that this empirical method determined the rock mass strength and deformation properties of weak to very weak rock mass environment and addressed the rock heterogeneity in the best way. The details of the GSI, as an empirical estimation tool, are discussed in the following.
5.1. Estimation of the Generalized H-B Failure Criterion Constants and Mohr-Coulomb Failure Constants. Hoek and Brown, in 1980 [61, 74, 75], proposed the nonlinear failure criterion as given in equation (11) for estimation of intact rock strength based on a wide range of triaxial tests on intact rock samples.

$$
\sigma_{1}=\sigma_{3}+\sqrt{m \mathrm{Co}_{3}+s \mathrm{Co}^{2}},
$$

where $\sigma_{1}$ and $\sigma_{3}$ are major and minor principal stresses, respectively, Co is the uniaxial compressive strength, and $m$ and $s$ are Hoek and Brown constants. Equation (11) can also denoted as

$$
\sigma_{1}=\sigma_{3}+\sigma_{c i}\left(m \frac{\sigma_{3}}{\sigma_{c i}}+s\right)^{0.5} .
$$

The Hoek and Brown failure criterion is updated from time to time in accordance to experience gained and to address certain practical limitations [29, 44, 61, 76]. Hoek and Brown developed a generalized failure criterion, also known as 2002 edition, to estimate jointed rock mass strength as given in the following equation $[11,13,42$, $48,49,76,77]$ :

$$
\sigma_{1}=\sigma_{3}+\sigma_{c}\left(m_{b} \frac{\sigma_{3}}{\sigma_{c}}+s\right)^{a},
$$

where $m_{b}, s$, and $a$ are material constants. Hoek and Brown constants are determined by equations (14)-(16), respectively, when the GSI value and $D$ are known $[78,79]$. The other empirical methods are used to determine the Hoek and Brown constants.

$$
\begin{aligned}
& m_{b}=m_{i} \exp \left(\frac{\mathrm{GSI}-100}{28-14 D}\right)^{a}, \\
& s=\exp \left(\frac{\mathrm{GSI}-100}{9-3 D}\right), \\
& a=0.5+\frac{1}{6}\left(e^{-\mathrm{GS} / 15}-e^{-20 / 3}\right),
\end{aligned}
$$

where $D$ is a disturbance factor which depends on the nature of the blast and $m_{i}$ is the intact rock constant.

The Hoek-Brown constants $m_{b}, s$, and $a$ for jointed rock mass are determined using the following equations without disturbance factor $(D)$ or when the $D$ value is zero (control blast of excavation by TBM) [52].

When the GSI value is estimated, then the following equation is used to determine the value of $m_{b}$ :

$$
m_{b}=m_{i} \exp \left(\frac{\mathrm{GSI}-100}{28}\right) \text {. }
$$

When GSI $>25$, then $s$ is calculated from the following equation as

$$
s=\exp \left(\frac{\mathrm{GSI}-100}{9}\right) .
$$

For good quality of rock mass, 


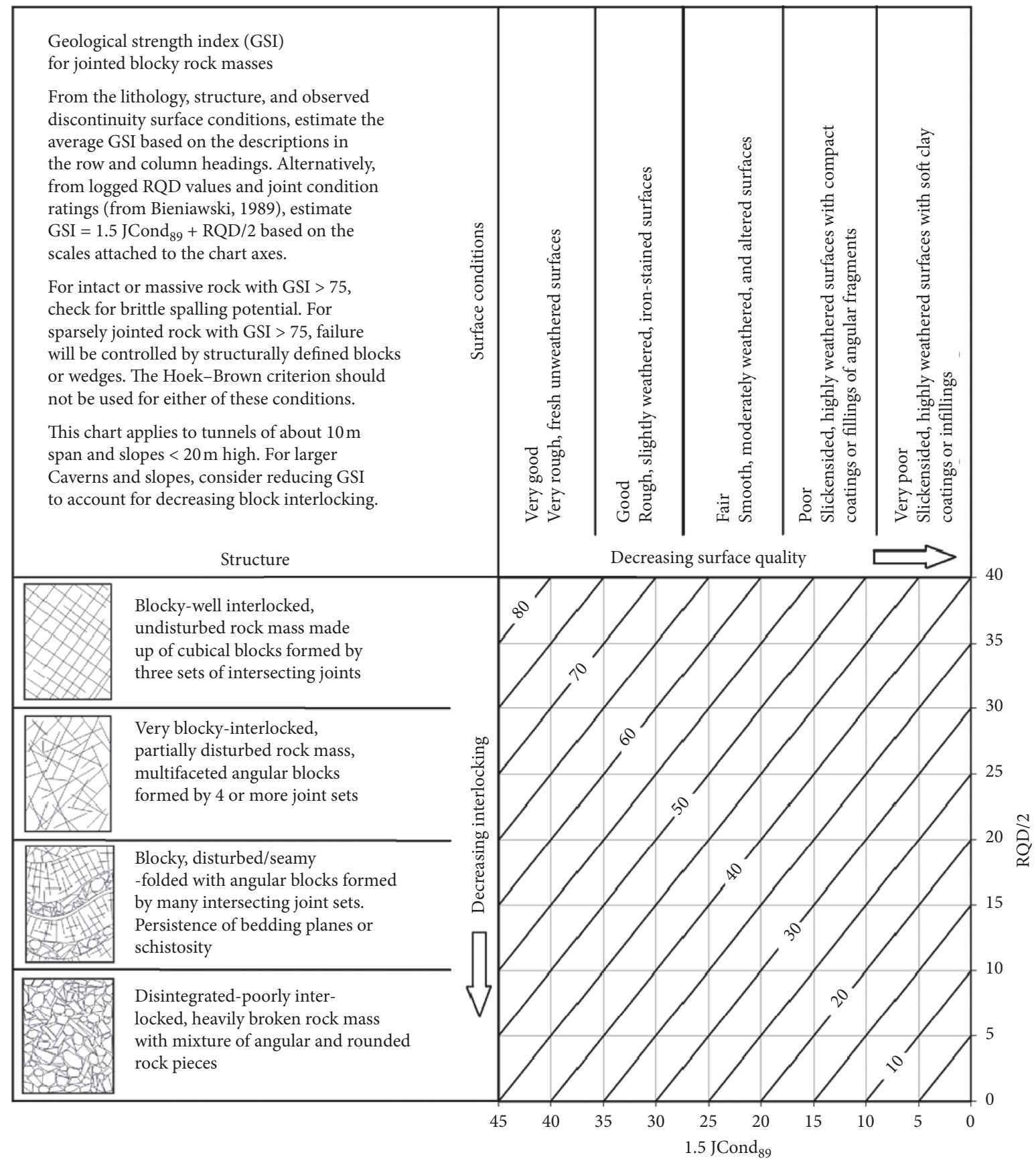

FIGURE 9: GSI showing scale A represented by 1.5 JCond $_{89}$ and scale B by RQD/2 [13].

$$
a=0.5 \text {. }
$$

When GSI $<25$, then the rock mass is of poor quality, and

$$
s=0
$$

And the value of $a$ is determined by the following equation:

$$
a=0.65-\frac{\mathrm{GSI}}{200}
$$

The Mohr-Coulomb failure criterion is also called as the linear failure criterion which is used in estimation of strength of rocks for design purpose. The constants, i.e., cohesion $\left(C_{m}\right)$ and angle of internal friction $\left(\varphi_{m}\right)$, or shear strength parameters are empirically estimated using 
equations (22) and (23) [80, 81], respectively, when intact rock and rock mass constants $\left(m_{b}, s\right.$, and $\left.a\right)$ are known:

$$
\begin{aligned}
C_{m} & =\frac{\sigma_{c i}\left[(1+2 a) s+(1-a) m_{b} \sigma_{3} n\right]\left(m_{b} \sigma_{3} n+s\right)^{a-1}}{(1+a)(2+a) \sqrt{1+\left(6 a m_{b}\left(m_{b} \sigma_{3} n+s\right)^{a-1} /(1+a)(2+a)\right)}} \\
\varphi_{m} & =\sin ^{-1}\left[\frac{3 a m_{b}\left(m_{b} \sigma_{3} n+s\right)^{a-1}}{(1+a)(2+a)+3 a m_{b}\left(m_{b} \sigma_{3} n+s\right)^{a-1}}\right] .
\end{aligned}
$$

When the GSI value is known, then equations (14)-(21) can be used to find the values of $m_{b}, s$, and $a$ for estimation of cohesion and angle of internal friction.

\subsection{Estimation of the Rock Mass Deformation Modulus.} Rock mass deformation modulus is an integral parameter for numerical modeling of rock engineering problems for pre and post failure analysis and assessment of the effectiveness of design [7]. The determination of rock mass deformation modulus in the field is a very challenging job, and the obtained results may be questionable due to complicated procedures $[7,38,59,61,73,82]$. Therefore, most of the researchers prefer to estimate the rock mass deformation modulus rather than determining in the field through in situ techniques $[49,59,69-73,77,82-85]$. The empirical models developed based on GSI values for rock mass deformation modulus are presented in Table 2.

\subsection{Estimation of the Rock Mass Strength and Poisson's Ratio.} The strength and passion ratio are very important parameters used in numerical modeling of rock engineering problems for evaluating the behavior of rock mass. The in situ determination of these properties of rock mass using different methods is difficult and time-consuming as compared to empirical methods [7]. The following are different empirical models using GSI and other parameters for estimation of strength and Poisson's ratio of a rock mass.

Ramamurthy, in 1993, established an empirical model using GSI and $\sigma_{c}$ (compressive strength of the rock) for estimating the compressive strength of rock mass as given in the following equation [91]:

$$
\sigma_{c} m=\sigma_{c} e^{(\text {GSI- 100)/18.5 }} \text {. }
$$

Vásárhelyi in 2009 [93], developed linear empirical models, as shown in equations (36) and (37), for estimation of Poisson's ratio using GSI, Poisson's ratio for intact rock $\left(v_{i}\right)$, and Hoek-Brown constant $\left(m_{i}\right)$ [93]:

$$
\begin{aligned}
& v r m=-0.002 \mathrm{GSI}+v_{i}+0.2, \\
& v r m=-0.002 \mathrm{GSI}-0.003 m_{i}+0.457,
\end{aligned}
$$

where $v r m$ is Poisson's ratio for rock mass and $v_{i}$ is intactrock Poisson's ratio.
5.4. Relation of GSI with Other Rock Mass Classification Systems. Hoek and Diederichs developed an alternate equation for estimation of the GSI using surface joint characteristics/ratio, as shown in the following equation [46]:

$$
\mathrm{GSI}=1.5 \mathrm{JCOND} 89+\frac{\mathrm{RQD}}{2} .
$$

Equation (38) can be rearranged to estimate the value of RQD, as shown in the following equation:

$$
\mathrm{RQD}=2(\mathrm{GSI}-1.5 \mathrm{JCOND} 89) \text {. }
$$

Barton et al., in 1974, suggested a relation representing the detail of joint condition (joint alteration $(\mathrm{Ja})$, joint roughness $(J r))$ as given in the following equation:

$$
\text { JCOND89 }=35\left(\frac{J r / J a}{1+(J r / J a)}\right) .
$$

Substituting equation (40) into equation (39), we will get

$$
\mathrm{RQD}=2(\mathrm{GSI}-52.5)\left(\frac{J r / J a}{1+(J r / J a)}\right) .
$$

Various researchers, worldwide, have developed different correlations for estimating the GSI value using $\mathrm{RMR}_{76}$, $\mathrm{RMR}_{89}, \mathrm{Q}$ value, RMR, RCR, RSR, and RMI as shown in Table 3.

5.5. Application of the GSI System in Stability Analysis of Slope, Tunnels, and Excavations. Sonmez and Ulusay, in 1999 [52], developed a refine quantitative numerical basis for estimating the GSI value, as shown in Figure 5. They used disturbance factor due to the method of excavation (mode of blasting) and rock mass strength for estimating the GSI value. For stability of slopes, they used the GSI value as the input in HOBRSLP software for slope stability analysis of circular and noncircular slip surfaces. In 2013, Hoek et al. [13] presented a simplified qualitative approach for stability analysis of tunnels having s span of $10 \mathrm{~m}$ and slopes having a height less than $20 \mathrm{~m}$. For larger caverns and slopes, consider reducing value of the GSI for decreasing block interlocking. Furthermore, the GSI value is usually used as an input parameter in RocLab software for evaluating different strength parameters of rock mass and numerical tools such as $R S^{2}$ and $R S^{3}$ developed by Rocscience, for numerical 
TABLE 2: Empirical models for rock mass deformation modulus.

\begin{tabular}{|c|c|c|c|c|c|c|c|}
\hline $\begin{array}{l}\text { S. } \\
\text { no }\end{array}$ & $\begin{array}{c}\text { Empirical } \\
\text { model }\end{array}$ & Unit & $\begin{array}{l}\text { Name of the } \\
\text { researcher }\end{array}$ & Parameters & Year & References & $\begin{array}{c}\text { Equation } \\
\text { no. }\end{array}$ \\
\hline 1 & $\begin{array}{c}E r m=E i\left(s^{a}\right)^{0.4} E i=50 \mathrm{GPa}, s=e^{((\mathrm{GSI}-100) / 9)} \\
a=0.5+(1 / 6)\left(e^{(-\mathrm{GSI} / 15)}-e^{(-20 / 3)}\right)\end{array}$ & $\mathrm{GPa}$ & Sonmez et al. & $\begin{array}{l}E i, \text { GSI, } s, \\
\text { and } a\end{array}$ & 2004 & [86] & $(24)$ \\
\hline 2 & $\operatorname{Erm}=(1-(D / 2)) \sqrt{\left(\sigma_{c} / 100\right)} 10^{((\mathrm{GSI}-10) / 40)}$ for $\sigma_{c}<100 \mathrm{MPa}$ & $\mathrm{GPa}$ & Hoek et al. & $\begin{array}{c}\text { GSI, } D \text {, and } \\
\sigma_{c}\end{array}$ & 2002 & {$[78]$} & $(25)$ \\
\hline 3 & $E r m=(1-(D / 2)) 10^{((G S I-10) / 40)}$ for $\sigma_{c}>100 \mathrm{MPa}$ & $\mathrm{GPa}$ & Hoek et al. & $\begin{array}{c}\text { GSI, } D \text {, and } \\
\sigma_{c}\end{array}$ & 2002 & [78] & $(26)$ \\
\hline 5 & $E r m=E i\{0.02+((1-(D / 2)) /(1+\exp ((60+15 D-\mathrm{GSI}) / 11)))\}$ & $\mathrm{MPa}$ & $\begin{array}{l}\text { Hoek and } \\
\text { Diederichs }\end{array}$ & $\begin{array}{l}\text { GSI, } D \text {, and } \\
E i\end{array}$ & 2006 & {$[77]$} & $(27)$ \\
\hline 6 & $E r m=10^{5}\{((1-(D / 2)) /(1+\exp ((75+25 D-G S I) / 11)))\}$ & $\mathrm{MPa}$ & $\begin{array}{l}\text { Hoek and } \\
\text { Diederichs }\end{array}$ & GSI and $D$ & 2006 & {$[77]$} & $(28)$ \\
\hline 7 & $E r m=E i\left(e^{(\mathrm{GSI}-100) / A}\right)$ & $\mathrm{GPa}$ & $\begin{array}{l}\text { Ván and } \\
\text { Vasarhelyi }\end{array}$ & $\begin{array}{l}\text { GSI, } E i \text {, } \\
\text { and } A\end{array}$ & 2010 & {$[87]$} & $(29)$ \\
\hline 8 & $E r m=\tan \left(\sqrt{\left.1.56+(\ln (\mathrm{GSI}))^{2}\right) \sqrt[3]{\sigma_{c}}}\right.$ & $\mathrm{GPa}$ & Beiki et al. & GSI and $\sigma_{c}$ & 2010 & {$[88]$} & $(30)$ \\
\hline 9 & $\operatorname{Erm}=\sqrt{\left(\sigma_{c} / 100\right)} * 10^{(\mathrm{GSI}-10) / 40}$ for $\sigma_{c}<100 \mathrm{MPa}$ & $\mathrm{GPa}$ & $\begin{array}{l}\text { Palmström } \\
\text { and Singh }\end{array}$ & $\sigma_{c}$ and GSI & 1998 & {$[89]$} & $(31)$ \\
\hline 10 & $\operatorname{Erm}=E i(s)^{3 / 4}$, where $s=e^{((\mathrm{GSI}-100) / 9)}$ & $\mathrm{GPa}$ & Sonmez et al. & $\begin{array}{l}E i \text {, GSI, } \\
\text { and } s\end{array}$ & 2004 & {$[59]$} & $(32)$ \\
\hline 11 & $E r m=0.35 * \exp ^{0.06 \mathrm{GSI}}$ & $\mathrm{GPa}$ & Maj & GSI & 2012 & {$[90]$} & (33) \\
\hline 12 & $E r m=\sqrt{(E i / 100)} 10^{((G S I-20) / 35)}$ & $\mathrm{GPa}$ & Majdi et al. & GSI & 2012 & {$[90]$} & $(34)$ \\
\hline
\end{tabular}

TABLE 3: Comparison of various correlations among the rock mass classifications.

\begin{tabular}{|c|c|c|c|c|c|}
\hline S. no. & Authors & Correlation & Estimated parameter & Reference & Equation no. \\
\hline 1 & Hoek and Brown & $\mathrm{GSI}=\mathrm{RMR}_{76} \ldots \mathrm{RMR}_{76}>18$ & GSI from $\mathrm{RMR}_{79}$ & [61] & $(42)$ \\
\hline 2 & Hoek and Brown & $\mathrm{GSI}=\mathrm{RMR}_{89}-5 \ldots \mathrm{RMR}_{89}>23$ & GSI from $\mathrm{RMR}_{89}$ & {$[61]$} & $(43)$ \\
\hline 3 & Morales et al. & $\mathrm{GSI}=4.714+0.687 \mathrm{RMR}$ & GSI from $\mathrm{RMR}_{89}$ & [94] & (44) \\
\hline \multirow[b]{2}{*}{4} & \multirow{2}{*}{ Coşar } & $\mathrm{GSI}=0.42 \mathrm{RMR}+23.07$ & GSI from $\mathrm{RMR}_{89}$ & [95] & $(45)$ \\
\hline & & $\mathrm{GSI}=1.61 \mathrm{Ln} Q+42.99$ & GSI from $Q$ & [95] & $(46)$ \\
\hline 5 & Osgoui and Ünal & $\mathrm{GSI}=6 e^{0.05 \mathrm{RMR}}$ & GSI from $\mathrm{RMR}_{89}$ & [51] & $(47)$ \\
\hline \multirow{2}{*}{6} & \multirow{2}{*}{ Hashemi et al. } & $\mathrm{GSI}_{(\text {Hoek }, 1995)}=0.692 \mathrm{RMR}_{89}+22.32$ & GSI from $\mathrm{RMR}_{89}$ & [84] & $(48)$ \\
\hline & & $\mathrm{GSI}_{(\text {Hoek }, 1995)}=0.917 \mathrm{GSI}_{(\mathrm{Cai}, 2004)}+3.18$ & GSI from GSI & [84] & (49) \\
\hline 7 & Irvani et al. & GSI $=1.35 \mathrm{RMR}-16.4$ & GSI from $\mathrm{RMR}_{89}$ & [96] & $(50)$ \\
\hline 8 & Singh and Tamrakar & $\mathrm{GSI}=0.73 \mathrm{RMR}-4.38$ & GSI from $\mathrm{RMR}_{89}$ & [65] & $(51)$ \\
\hline \multirow[t]{4}{*}{9} & Zhang et al. & $\mathrm{GSI}=1.21 \mathrm{RMR}-18.61$ & GSI from $\mathrm{RMR}_{89}$ & [50] & $(52)$ \\
\hline & & $\mathrm{GSI}=0.5939 \mathrm{RMR}_{\mathrm{Basic}}^{1.1047}$ & GSI from $\mathrm{RMR}_{\text {Basic }}$ & & (53) \\
\hline & & $\mathrm{GSI}=0.9143 \mathrm{RMR}+6.132$ & GSI from $\mathrm{RMR}_{89}$ & & $(54)$ \\
\hline & & $\mathrm{GSI}=12.638 \mathrm{Ln} Q+28.538$ & GSI from $Q$ & & (55) \\
\hline \multirow{5}{*}{10} & Sodeobi et al & $\mathrm{GSI}=10.951 \mathrm{LnRMi}+33.157$ & GSI from RMi & [07] & $(56)$ \\
\hline & Sadegh1 et al. & $\mathrm{GSI}=29.891 \operatorname{LnRSR}-71.285$ & GSI from RSR & [97] & (57) \\
\hline & & $\mathrm{GSI}=1.7 \mathrm{RCR}^{0.8566}$ & GSI from RCR & & $(58)$ \\
\hline & & $\mathrm{GSI}=25.577 Q_{N}^{0.2841}$ & GSI from $Q_{N}$ & & $(59)$ \\
\hline & & $\mathrm{GSI}=0.7861 \mathrm{GSI}_{\mathrm{Cai}}+8.5483$ & GSI from GSI & & $(60)$ \\
\hline
\end{tabular}

modeling, stability analysis of engineering structures, and pre- and postbehavior of rock mass (tunnels, slopes, and excavations). The value of RMR, Q-system, and other empirical methods is not used as compared to the GSI value directly in numerical tools, but indirectly, the support system recommended by these empirical methods is installed and evaluated in numerical modeling.

5.6. Application of the GSI in Excavatability Assessment of Rock Masses. GSI system has been successfully utilized in excavability assessment of rock mass during construction of underground excavation. The mode of excavation is defined based on 61 site investigations including sedimentary and metamorphic rocks having deformed structures and joint conditions utilizing the GSI value by Tsiambaos and Saroglou [98]. The research study concluded that (1) when GSI value $>65$ and point load index $\left(\mathrm{Is}_{50}\right)>3 \mathrm{MPa}$ and GSI value $>60$ and $\mathrm{Is}_{50}<3 \mathrm{MPa}$, blasting is preferred to be used in massive blocky, having tight joint conditions. (2) When the GSI value ranges from 20 to 45 and Is $_{50} \geq 3 \mathrm{MPa}$ and the GSI value ranges from 25 to 55 and $\mathrm{Is}_{50}<3 \mathrm{MPa}$, excavation is carried out by ripping, while in the transition phase from blasting to ripping, the hyudraulic breaker is to be used for excavation. This excavability assessment is suitable to be used in rock mass, where discontinuities control the excavation, while it is not suitable in heterogeneous rock masses such as sheared flysch, bimrocks, and soft rocks. 


\section{Limitations}

The GSI system is based on assumptions that the rock mass behaves like isotropic media, and the behavior of rock mass is not reliant on the direction of the applied load. Based on GSI assumptions, this system should not be used in such conditions where predominant structural orientation and structurally dependent gravitational instability exist.

The GSI system is not applied to already excavated faces in very hard rock having few discontinuities spaced at distances of similar magnitude to the dimensions of the tunnel or slope under consideration, because in this case, the stability of the tunnel or slope is controlled by the threedimensional geometry of the intersecting discontinuities and the free faces created by the excavation.

The quantitative version of the GSI developed by $\mathrm{H}$ Sonmez and Ulusay is valid to use in such cases in which frequency and orientation of discontinuities are measured easily. The quantification version of the GSI is not effective in tectonically disturbed rock masses having destroyed structural fabric. In such a case, the researchers recommend using a qualitative version of the GSI based on careful visual observations.

\section{Conclusions}

The following conclusions are drawn from this study:

(1) The empirical methods such as RMR, $Q$, and RMI used RQD as input parameters which are not suitable to be applied in a very weak and highly jointed rock mass environment because for such rock mass conditions, RQD value is taken as zero.

(2) The empirical methods (RMR, Q-system, RMI, etc.) are inconvenient to be used for design of tunnels, caverns, and other underground excavations in squeezing, high-stress, and weak rock mass environments.

(3) The empirical methods (RMR, Q-system, RMI, etc.) are not suitable to be used for prepost failure and stability analysis of engineering projects through numerical modeling.

(4) The GSI system, as compared to other rock mass classification systems, may represent the heterogeneity of rock mass in a convenient way in terms of rock mass structure domain.

(5) Three different approaches are effectively used to estimate the GSI value, i.e., qualitative, quantitative, and empirical models based on other empirical methods. The qualitative and quantitative approaches are suitable to be used for evaluating the weak, jointed, layered, and heterogeneous rock mass for engineering design purpose.

(6) It has been concluded from the study that the RMR, Q-system, and other empirical methods are convenient to be used in favorable joint conditions or presence of less joints in the hard rock mass environment, while the GSI system is recommended to be used for weak to very weak and high-stress rock mass environments.

(7) The GSI system is explicitly used for estimation of geomechanical properties of rock mass with maximum confidence level as compared to other rock mass classification systems.

(8) GSI has a wide range of applications in rock engineering. However, this system did not cover the design of the support system for tunnel and other structures as compared to RMR and Q-system.

(9) The qualitative approach for estimating the GSI system required better knowledge and skills about collecting and evaluating the field data. However, the quantitative and empirical model approaches are easy to be used for the assessment of rock mass environment.

(10) This study will provide a common understanding to field professionals to use different estimating approaches for the GSI value in a convenient way for evaluating the rock mass environment and estimating the required rock mass strength and deformation properties for numerical modeling.

\section{Data Availability}

The data used to support the findings of this study are included within the article.

\section{Conflicts of Interest}

The authors declare that there are no conflicts of interest regarding the publication of this paper.

\section{Supplementary Materials}

Figure 1: GSI charts for confined and fissile molaissic rock masses for tunnels and surface excavations, respectively [64]; Hoek et al., in 2005 [64], incorporated weak, heterogeneous rock masses and lithological variability of a rock mass. Hoek et al. developed two charts for confined and fissile molaissic rock masses for tunnels and surface excavations, as presented in Figures 1(a) and 1(b), respectively. Figure 2: scale A and $\mathrm{B}$ inserted at $x$ - and $y$-axis of the GSI chart [13]. (Supplementary Materials)

\section{References}

[1] L. Jing, "A review of techniques, advances and outstanding issues in numerical modelling for rock mechanics and rock engineering," International Journal of Rock Mechanics and Mining Sciences, vol. 40, no. 3, pp. 283-353, 2003.

[2] M. N. Bidgoli, Z. Zhao, and L. Jing, "Numerical evaluation of strength and deformability of fractured rocks," Journal of Rock Mechanics and Geotechnical Engineering, vol. 5, no. 6, pp. 419-430, 2013.

[3] L. Jing and J. A. Hudson, "Numerical methods in rock mechanics," International Journal of Rock Mechanics and Mining Sciences, vol. 39, no. 4, pp. 409-427, 2002.

[4] J. A. Hudson and X.-T. Feng, "Technical auditing of rock mechanics modelling and rock engineering design," 
International Journal of Rock Mechanics and Mining Sciences, vol. 47, no. 6, pp. 877-886, 2010.

[5] T. Dalgleish, Engineering Rock Mechanics, vol. 136, no. 1, 2007.

[6] M. Pinheiro, X. Emery, T. Miranda, L. Lamas, and M. Espada, "Modelling geotechnical heterogeneities using geostatistical simulation and finite differences analysis," Minerals, vol. 8, no. 2, pp. 52-19, 2018.

[7] S. Hussain, M. Khan, Z. Ur Rahman et al., "Evaluating the predicting performance of indirect methods for estimation of rock mass deformation modulus using inductive modelling techniques," Journal of Himalayan Earth Sciences, vol. 51, no. 1, pp. 61-74, 2018.

[8] S. Hussain, N. Mohammad, M. Tahir, Z. Ur Rehman, and N. Mohammad, "Rock mass characterization along the tunnel axis for Golen Gol hydropower project Chitral, Pakistan," Journal of Himalayan Earth Sciences, vol. 49, no. 2, pp. 75-83, 2016.

[9] Z. Ur Rehman, N. Mohammad, S. Hussain, and M. Tahir, "Numerical modeling for the engineering analysis of rock mass behaviour due to sequential enlargement of Lowari tunnel Chitral Khyber Pakhtunkhwa, Pakistan," International Journal of Geotechnical Engineering, vol. 13, no. 1, pp. 1-7, 2019.

[10] S. Hussain, Z. Ur Rehman, N. Mohammad et al., "Numerical modeling for engineering analysis and designing of optimum support systems for headrace tunnel," Advances in Civil Engineering, vol. 2018, Article ID 7159873, 10 pages, 2018.

[11] E. Hoek and E. T. Brown, "The Hoek-Brown failure criterion and GSI-2018 edition," Journal of Rock Mechanics and Geotechnical Engineering, vol. 11, no. 3, pp. 445-463, 2019.

[12] G. F. Andriani and M. Parise, "Applying rock mass classifications to carbonate rocks for engineering purposes with a new approach using the rock engineering system," Journal of Rock Mechanics and Geotechnical Engineering, vol. 9, no. 2, pp. 364-369, 2017.

[13] E. Hoek, T. G. Carter, and M. S. Diederichs, "Quantification of the geological strength index chart," in Proceedings of the 47th US Rock Mechanics/Geomechanics Symposium, San Francisco, CA USA, 2013.

[14] V. Marinos and T. G. Carter, "Maintaining geological reality in application of GSI for design of engineering structures in rock," Engineering Geology, vol. 239, pp. 282-297, 2018.

[15] K. Terzaghi, Rock Defects and Loads on Tunnel Supports, Harvard University, Cambridge, MA, USA, 1946.

[16] H. Lauffer, "Gebirgsklassifizierung fur den Stol Lenbau," Geology Bauwesen, vol. 24, pp. 46-51, 1958.

[17] D. U. Deere, "Technical description of rock cores for engineering purposes," Rock Mechanics and Engineering Geology, Springer, Berlin, Germany, 1963.

[18] D. U. Deere and R. P. Miller, Engineering Classification and Index Properties for Intact Rock, National Technical Information Service, Springfield, VA, USA, 1966.

[19] G. E. Wickham, H. R. Tiedemann, and E. H. Skinner, "Support determinations based on geologic predictions," in Proceedings of the North American Rapid Excavation and Tunneling Conference, pp. 5-7, Chicago, IL, USA, 1972.

[20] Z. T. Bieniawski, Engineering Rock Mass Classifications: A Complete Manual for Engineers and Geologists in Mining, Civil, and Petroleum Engineering, Wiley, Hoboken, NJ, USA, 1989.

[21] Z. T. Bieniawski, Engineering Classification of Jointed Rock Masses, South African Institute of Civil Engineers, Midrand, South Africa, 1973.
[22] N. Barton, R. Lien, and J. Lunde, "Engineering classification of rock masses for the design of tunnel support," Rock Mechanics, vol. 6, pp. 189-236, 1974.

[23] G. J. Pacher and L. Rabcewicz, "Zum der seitigen stand der gebirgs e klassifizierung in stollen-und tunnelbau," in Proceedings of the 22nd Geomechanics Colloquia, p. 51, 1974.

[24] J. A. Franklin, "Safety and economy in tunneling," in Proceedings of the 10th Canadian Rock Mechanics Symposium, pp. 27-53, Kingston, Canada, 1975.

[25] ISRM, "Commission on classification of rocks and rock masses: basic geotechnical description of rock masses," International Journal of Rock Mechanics and Mining Science \& Geomechanics Abstracts, vol. 2, pp. 85-110, 1981.

[26] A. F. H. Stille and T. Groth, FEM-analysis of Rock Mechanics Problems by JOBFEM, Swedish Rock Engineering Research Foundation Publication, Stockholm, Sweden, 1982.

[27] D. A. Williamson and C. R. Kuhn, "The unified rock classification system," in Rock Classification Systems for Engineering Purposes, ASTM, West Conshohocken, PA, USA, 1984.

[28] A. Palmström, RMi-a Rock Mass Characterization System for Rock Engineering Purposes, University of Oslo, Oslo, Norway, 1995.

[29] E. Hoek and P. K. Kaiser, Support of Underground Excavations in Hard Rock, CRC Press, Boca Raton, FL, USA, 1997.

[30] N. Barton, "TBM perfomance estimation in rock using QTBM," Tunnel and Tunnelling International, pp. 30-34, 1999.

[31] Z. Şen and B. H. Bahaaeldin, "Modified rock mass classification system by continuous rating," Engineering Geology, vol. 67, pp. 269-280, 2003.

[32] Z. T. Bieniawski von Prein, B. C. Tamames, J. M. Galera Fernández, and M. Hernández Álvarez, "Rock mass excavability indicator: new way to selecting the optimum tunnel construction method," Tunnelling and Underground Space Technology, vol. 3, p. 237, 2006.

[33] Ö. Aydan, R. Ulusay, and N. Tokashiki, "Rock mass quality rating (RMQR) system and its application to the estimation of geomechanical characteristics of rock masses," in Engineering Geology for Society and Territory -Volume 6: Applied Geology for Major Engineering Projects, Springer, Berlin, Germany, 2015.

[34] M. Mohammadi and M. F. Hossaini, "Modification of rock mass rating system: interbedding of strong and weak rock layers," Journal of Rock Mechanics and Geotechnical Engineering, vol. 9, no. 6, pp. 1165-1170, 2017.

[35] C. Saroglou, S. Qi, S. Guo, and F. Wu, "ARMR, a new classification system for the rating of anisotropic rock masses," Bulletin of Engineering Geology and the Environment, vol. 78, no. 5, pp. 3611-3626, 2019.

[36] H. Rehman, W. Ali, A. Naji, J.-j. Kim, R. Abdullah, and H.-k. Yoo, "Review of rock-mass rating and tunneling quality index systems for tunnel design: development, refinement, application and limitation," Applied Sciences, vol. 8, no. 8, p. 1250, 2018.

[37] X. Wang, J. Lai, R. S. Garnes, and Y. Luo, "Support system for tunnelling in squeezing ground of Qingling-Daba mountainous area: a case study from soft rock tunnels," Advances in Civil Engineering, vol. 2019, Article ID 8682535, 17 pages, 2019.

[38] M. Romana, J. B. Serón, and E. Montalar, "SMR geomechanics classification: application, experience and validation," in Proceedings of the 10th ISRM Congress, Sandton, South Africa, September 2003. 
[39] R. Bertuzzi, "Revisiting rock classification to estimate rock mass properties," Journal of Rock Mechanics and Geotechnical Engineering, vol. 11, no. 3, pp. 494-510, 2019.

[40] P. Marinos, V. Marinos, and E. Hoek, The Geological Strength Index (GSI): A Characterization Tool for Assessing Engineering Properties of Rock Masses, Taylor and Francis, Abingdon, UK, 2007.

[41] V. Marinos, P. Marinos, and E. Hoek, "The geological strength index: applications and limitations," Bulletin of Engineering Geology and the Environment, vol. 64, no. 1, pp. 55-65, 2005.

[42] P. Marinos, E. Hoek, and V. Marinos, "Variability of the engineering properties of rock masses quantified by the geological strength index: the case of ophiolites with special emphasis on tunnelling," Bulletin of Engineering Geology and the Environment, vol. 65, pp. 129-142, 2006.

[43] E. Hoek, P. Marinos, and M. Benissi, "Applicability of the geological strength index (GSI) classification for very weak and sheared rock masses. The case of the Athens Schist formation," Bulletin of Engineering Geology and the Environment, vol. 57, no. 2, pp. 151-160, 1998.

[44] E. Hoek, D. Wood, and S. Shah, "A modified Hoek-Brown criterion for jointed rock masses," in Proceedings of the Rock Mechanic Symposium, pp. 209-214, Chester, UK, 1992.

[45] P. Marinos and E. Hoek, "Estimating the geotechnical properties of heterogeneous rock masses such as Flysch," Bulletin of Engineering Geology and the Environment, vol. 60, no. 2, pp. 85-92, 2001.

[46] E. Hoek and M. S. Diederichs, "Quantification of the geological strength index chart," in Proceedings of the 2013 US Rock Mechanics/Geomechanics Symposium, San Francisco, CA, USA, 2013.

[47] H. Sönmez and R. Ulusay, "A discussion on the Hoek-Brown failure criterion and suggested modifications to the criterion verified by slope stability case studies," Bulletin of Earth Sciences, vol. 26, pp. 77-99, 2002.

[48] P. Marinos and E. Hoek, "GSI: a geologically friendly tool for rock mass strength estimation," in Proceedings of the 2000 International Conference on Geotechnical and Geological Engineering, Melbourne, Australia, 2000.

[49] M. Cai, P. K. Kaiser, H. Uno, Y. Tasaka, and M. Minami, "Estimation of rock mass deformation modulus and strength of jointed hard rock masses using the GSI system," International Journal of Rock Mechanics and Mining Sciences, vol. 41, no. 1, pp. 3-19, 2004.

[50] Q. Zhang, X. Huang, H. Zhu, and J. Li, "Quantitative assessments of the correlations between rock mass rating (RMR) and geological strength index (GSI)," Tunnelling and Underground Space Technology, vol. 83, pp. 73-81, 2019.

[51] R. R. Osgoui and E. Ünal, "An empirical method for design of grouted bolts in rock tunnels based on the geological strength index (GSI)," Engineering Geology, vol. 107, no. 3-4, pp. 154-166, 2009.

[52] H. Sonmez and R. Ulusay, "Modifications to the geological strength index (GSI) and their applicability to stability of slopes," International Journal of Rock Mechanics and Mining Sciences, vol. 36, pp. 743-760, 1999.

[53] K. Hong, E. Han, and K. Kang, "Determination of geological strength index of jointed rock mass based on image processing," Journal of Rock Mechanics and Geotechnical Engineering, vol. 9, no. 4, pp. 702-708, 2017.

[54] H. Sonmez, C. Gokceoglu, and R. Ulusay, "An application of fuzzy sets to the geological strength index (GSI) system used in rock engineering," Engineering Applications of Artificial Intelligence, vol. 16, no. 3, pp. 251-269, 2003.
[55] G. Somodi, Á. Krupa, L. Kovács, and B. Vásárhelyi, "Comparison of different calculation methods of geological strength index (GSI) in a specific underground construction site," Engineering Geology, vol. 243, pp. 50-58, 2018.

[56] R. R. Osgoui, R. Ulusay, and E. Unal, "An assistant tool for the Geological Strength Index to better characterize poor and very poor rock masses," International Journal of Rock Mechanics and Mining Sciences, vol. 47, no. 4, pp. 690-697, 2010.

[57] N. Deisman, M. Khajeh, and R. J. Chalaturnyk, "Using geological strength index (GSI) to model uncertainty in rock mass properties of coal for CBM/ECBM reservoir geomechanics," International Journal of Coal Geology, vol. 112, pp. 76-86, 2013.

[58] Z. Gurocak, P. Solanki, and M. M. Zaman, "Empirical and numerical analyses of support requirements for a diversion tunnel at the Boztepe dam site, eastern Turkey," Engineering Geology, vol. 91, no. 2-4, pp. 194-208, 2007.

[59] H. Sonmez, C. Gokceoglu, H. A. Nefeslioglu, and A. Kayabasi, "Estimation of rock modulus: for intact rocks with an artificial neural network and for rock masses with a new empirical equation," International Journal of Rock Mechanics and Mining Sciences, vol. 43, no. 2, pp. 224-235, 2006.

[60] Z. T. Biniawski, "Classification of rock masses for engineering: the RMR system and future trends," in Rock Testing and Site Characterization, pp. 553-573, Elsevier, Amsterdam, Netherlands, 1993.

[61] E. Hoek and E. T. Brown, "Practical estimates of rock mass strength," International Journal of Rock Mechanics and Mining Sciences, vol. 34, no. 8, pp. 1165-1186, 1997.

[62] D. U. Deere, Rock Quality Designation (RQD) after 20 Years, Engineer Waterways Library, Vicksburg, MS, USA, 1989.

[63] E. Hoek, "Strength of rock and rock masses," ISRM News Journal, vol. 2, pp. 4-16, 1994.

[64] E. Hoek, P. G. Marinos, and V. P. Marinos, "Characterisation and engineering properties of tectonically undisturbed but lithologically varied sedimentary rock masses," International Journal of Rock Mechanics and Mining Sciences, vol. 42, no. 2, pp. 277-285, 2005.

[65] J. L. Singh and N. K. Tamrakar, "Rock mass rating and geological strength index of rock masses of Thopal-Malekhu river areas, central Nepal lesser Himalaya," Bulletin of the Department of Geology, vol. 16, pp. 29-42, 2013.

[66] M. Rasouli, "Engineering geological studies of the diversion tunnel, focusing on stabilization analysis and support design, Iran," Engineering Geology, vol. 108, no. 3-4, pp. 208-224, 2009.

[67] S. K. Dwivedi, P. C. Adhikary, and J. M. a. N. Tamrakar, Engineering Geological and Geotechnical Characteristics of the Kankai Hydro-Power Tunnel in Soft Rock, Nepal, IAEG, Vienna, Austria, 2006.

[68] M. Genis, H. Basarir, A. Ozarslan, E. Bilir, and E. Balaban, "Engineering geological appraisal of the rock masses and preliminary support design, Dorukhan tunnel, Zonguldak, Turkey," Engineering Geology, vol. 92, no. 1-2, pp. 14-26, 2007.

[69] C. O. Aksoy, M. Geniş, G. Uyar Aldaş, V. Özacar, S. C. Özer, and Ö. Yılmaz, "A comparative study of the determination of rock mass deformation modulus by using different empirical approaches," Engineering Geology, vol. 131-132, pp. 19-28, 2012.

[70] V. K. Singh, D. Singh, and T. N. Singh, "Prediction of strength properties of some schistose rocks from petrographic properties using artificial neural networks," International Journal of Rock Mechanics and Mining Sciences, vol. 38, no. 2, pp. 269-284, 2001. 
[71] J. Shen, M. Karakus, and C. Xu, "A comparative study for empirical equations in estimating deformation modulus of rock masses," Tunnelling and Underground Space Technology, vol. 32, pp. 245-250, 2012.

[72] A. Kayabasi, C. Gokceoglu, and M. Ercanoglu, "Estimating the deformation modulus of rock masses: a comparative study," International Journal of Rock Mechanics and Mining Sciences, vol. 40, no. 1, pp. 55-63, 2003.

[73] J. Gholamnejad, H. R. Bahaaddini, and M. Rastegar, "Prediction of the deformation modulus of rock masses using artificial neural networks and regression methods," Journal of Mining \& Environment, vol. 4, no. 1, pp. 35-43, 2013.

[74] E. Eberhardt, "The Hoek-Brown failure criterion," Rock Mechanics and Rock Engineering, vol. 45, no. 6, pp. 981-988, 2012.

[75] E. Hoek and E. T. Brown, "Hoek-Brown failure criterion-a 1988 update," International Journal of Rock Mechanics and Mining Sciences \& Geomechanics Abstracts, 1990.

[76] E. Hoek, C. Carranza, and B. Corkum, "Hoek-Brown failure criterion-2002 edition," in Proceedings of the 2002 NarmsTac Conference, Toronto, Canada, 2002.

[77] E. Hoek and M. S. Diederichs, "Empirical estimation of rock mass modulus," International Journal of Rock Mechanics and Mining Sciences, vol. 43, no. 2, pp. 203-215, 2006.

[78] E. Hoek, C. C. Torres, and B. Corkum, "Hoek-Brown failure criterion-2002 edition," in Proceedings of the 5th North American Rock Mechanics Symposium, Toronto, Canada, 2002.

[79] E. Hoek and E. T. Brown, Underground Excavation in Rock, Institution of Mining and Metallurgy, London, UK, 1980.

[80] Y. C. Yang, X. G. Yang, and H. Ge Xing, "Estimation method for shear strength parameters of fault rock based on geological strength index," Electronic Journal of Geotechnical Engineering, vol. 21, no. 5, pp. 1715-1725, 2016.

[81] K.-S. Kang, N.-L. Hu, C.-S. Sin, S.-H. Rim, E.-C. Han, and C.-N. Kim, "Determination of the mechanical parameters of rock mass based on a GSI system and displacement back analysis," Journal of Geophysics and Engineering, vol. 14, no. 4, pp. 939-948, 2017.

[82] H. Mohammadi and R. Rahmannejad, "The estimation of rock mass deformation modulus using regression and artificial neural notworks analysis," Arabian Journal for Science and Engineering, vol. 35, no. 1, pp. 205-217, 2010.

[83] B. Figueiredo, L. Lamas, and J. Muralha, "Determination of in situ stresses using large flat jack tests," in Proceedings of the ISRM International Symposium 2010, New Delhi, India, 2010.

[84] M. Hashemi, Æ. S. Moghaddas, and R. Ajalloeian, "Application of rock mass characterization for determining the mechanical properties of rock mass: a comparative study," Rock Mechanics and Rock Engineering, vol. 43, pp. 305-320, 2010.

[85] E. Ghotbi Ravandi, R. Rahmannejad, A. E. Feili Monfared, and E. Ghotbi Ravandi, "Application of numerical modeling and genetic programming to estimate rock mass modulus of deformation," International Journal of Mining Science and Technology, vol. 23, no. 5, pp. 733-737, 2013.

[86] H. Sonmez, C. Gokceoglu, and R. Ulusay, "Indirect determination of the modulus of deformation of rock masses based on the GSI system," International Journal of Rock Mechanics and Mining Sciences, vol. 41, no. 5, pp. 849-857, 2004.

[87] P. Ván and B. Vasarhelyi, "Relation of rock mass characterization and damage," Rock Engineering in Difficult Ground Conditions (Soft Rocks and Karst), pp. 399-404, CRC Press, Boca Raton, FL, USA, 2010.
[88] M. Beiki, A. Bashari, and A. Majdi, "Genetic programming approach for estimating the deformation modulus of rock mass using sensitivity analysis by neural network," International Journal of Rock Mechanics and Mining Sciences, vol. 47, no. 7, pp. 1091-1103, 2010.

[89] A. Palmström and R. Singh, "The deformation modulus of rock masses-comparisons between in situ tests and indirect estimates," Tunnelling and Underground Space Technology, vol. 16, no. 2, pp. 115-131, 2001.

[90] A. Majdi, A. Bashari, and M. Beiki, "Estimation of rock mass deformation modulus based on GSI system," Harmonising Rock Engineering and the Environment, pp. 2113-2117, 2012.

[91] T. Ramamurthy, "Strength and modulus responses of anisotropic rocks," in Comprehensive Rock Engineering. Principle, Practice \& Projects, pp. 313-329, Elsevier, Amsterdam, Netherlands, 1993.

[92] B. Vásárhelyi, “A possible method for estimating the Poisson's rate values of the rock masses," Acta Geodaetica et Geophysica Hungarica, vol. 44, no. 3, pp. 313-322, 2009.

[93] E. Osgoui and R. Ünal, "Rock reinforcement design for unstable tunnels originally excavated in very poor rock mass. Underground space use in: analysis of the past and lessons for the future," in Proceedings of the International World Tunnel Congress and the 31st ITA General Assembly, pp. 291-296, Istanbul, Turkey, 2005.

[94] T. Morales, G. Uribe-Etxebarria, and J. A. Uriarte, "Geomechanical characterisation of rock masses in Alpine regions: the Basque arc (Basque-Cantabrian basin, northern Spain)," Engineering Geology, vol. 71, no. 3-4, pp. 343-362, 2004.

[95] S. Coşar, Application of rock mass classification systems for future support design of the Dim tunnel near Alanya, Ph.D. thesis, Middle East Technical University, Ankara, Turkey, 2004.

[96] I. Irvani, W. Wilopo, and D. Karnawati, "Determination of nuclear power plant site in west Bangka based on rock mass rating and geological strength index," Journal of Applied Geology, vol. 5, no. 2, 2015.

[97] S. Sadeghi, E. S. Teshnizi, and B. Ghoreishi, "Correlations between various rock mass classification/characterization systems for the Zagros tunnel-W Iran," Journal of Mountain Science, vol. 17, no. 7, 2020.

[98] G. Tsiambaos and H. Saroglou, "Excavatability assessment of rock masses using the geological strength index (GSI)," Bulletin of Engineering Geology and the Environment, vol. 69, no. 1, pp. 13-27, 2010. 